UDC 577.152.1

\title{
Lipoxygenase regulation in vivo and in vitro by lipid compounds
}

\author{
T. D. Skaterna, V. M. Kopich, G. I. Kharitonenko, O. V. Kharchenko \\ Institute of Bioorganic Chemistry and Petrochemistry, NAS of Ukraine \\ 1, Murmans'ka Str., Kyiv, Ukraine, 02660 \\ skaterna.t@ukr.net
}

\begin{abstract}
Lipoxygenases (LOs) are known as one of the enzymes of lipid peroxidation. The majority of LOs are soluble enzymes and have affinity to membranes. The enzyme translocation from a cytosol to a membrane surface is one of the stages of regulation of the amount of LO catalysis products in the cell. A sorption to the membrane surface is described for most LOs from plant and animal sources. This review presents the data about regulation of the LO activity by the lipid compounds - both natural and chemically modified. Lipids might regulate the LO activity through: protein-lipid interactions of C2 domain with the membrane, changes in the enzyme affinity, the LOs translocation, allosteric regulation, increase in the selectivity towards substrates. The regulatory effect of active compound on the enzyme activity depends on the lipophilicity of effectors. Considering the LO activity it is necessary to take into account the enzyme microenvironment and its influence on the range of the LO products.
\end{abstract}

Ke yw or d s: lipoxygenase, allosteric regulation, phospholipids, inhibition, activation.

Biological significance of the lipoxygenase pathway products in living organisms explains an interest paid to the research on regulation mechanisms of this key enzyme and a possibility to correct the level of lipoxygenase metabolites. Lipoxygenases (oxidoreductase, EC 1.13.11.- ; LO) are the enzymes of lipid metabolism, which catalyze the oxygen insertion into the 1,4-cis,cis-pentadiene fragment of polyunsaturated fatty acids (PUFAs) with production of the corresponding hydroperoxide derivatives (HP). The LO products of PUFAs oxidation pathways are diverse signal compounds, animals leukotrienes and lipoxynes, coral prostaglandin-like LO metabolites, lactones of microorganisms, plant jasmonates, etc. They are involved in the apoptosis and cell proliferation, metabolism and transportation, cell-cell interactions and inflammatory processes. The quantitative and qualitative composition of LO metabolites changes at various pathological conditions of animal, human and plant cells during the adaptation to environmental factors and at the conditions of intense growth and development. This is why the finding of new substances, which can regulate the LO activity, is a task of urgent importance.

The factors potentially able to regulate the 5-LO activity are as follows: 1 - factors changing the enzyme activity by facilitating the substrate accessibility; 2 - $\mathrm{Fe}^{2+}$ oxidation to $\mathrm{Fe}^{3+}$ active state; 3 - stabilization of the active 5-LO-form. Ions $\mathrm{Ca}^{2+}, \mathrm{Mg}^{2+}$, phospholipids, glycerol, membranes, ATP are capable of particular increasing the 5-LO activity. The hydroperoxides level also determines the 5-LO activity and regulates the redox state of ferrum in the active site. Posphorylation and interaction with the protein factors from polymorphonuclear leukocytes (coactosinlike protein up-regulates the $\mathrm{Ca}^{2+}$-induced 5-LO activity [1]) and the membrane associated protein FLAP (5-LO activating protein bounds with a nuclear membrane [2]) are related to the factors, which are able to control the enzyme activity in the cell.

(C) 2015 T. D. Skaterna et al.; Published by the Institute of Molecular Biology and Genetics, NAS of Ukraine on behalf of Biopolymers and Cell. This is an Open Access article distributed under the terms of the Creative Commons Attribution License (http://creativecommons.org/licenses/by/4.0/), which permits unrestricted reuse, distribution, and reproduction in any medium, provided the original work is properly cited 
In cells, 5-LO locates in a soluble form in cytosol (eosinophils, neutrophils, macrophages) or in a nuclear soluble compartment associated with chromatin (alveolar macrophages, Langerhans cells) [3-4]. In plants, the main pool of 13-LO products associates with inner and external plastids membranes [5-7]; 13-hydroperoxide lyase and allene oxide synthase are the enzymes, which utilize the products of 13-LO oxidation of linoleic (LA) and linolenic acids as the substrates and are also connected with inner and external plastids membranes respectively. The source of 9-hydroperoxides synthesis is predominantly the plant cytoplasmic membrane [5]. It was suggested that there is a connection between the LO activity of microsomal and mitochondrial membranes, but the data presented are insufficient [7-8]. 5-LO is also associated with the lipid rafts with proteinkinase C II and other rafts proteins which were demonstrated in the mantle cell lymphoma [9].

The substrates of LO reaction are polyunsaturated fatty acids that are a part of membrane phospholipids. The majority of LO are soluble enzymes and have affinity to membranes. Under cell stimulation, 5-LO migrates to the nuclear membrane where another enzyme phospholipase $\mathrm{A}_{2}$ liberates arachidonic acid (AA) from phospholipids during the reaction, which is utilized by 5-LO as a substrate. The membrane associated protein FLAP facilitates the substrate transport to 5-LO [10], which is connected with the nuclear membrane by amino acids. This protein can be phosphorylated by MAPK-activated proteinkinase (MAPKAPK)-2 and ERKs. Thus, FLAP controles the 5-LO products synthesis.

\section{Regulation of lipoxygenase activity by cell membrane compounds}

The main part of the LO reaction substrates, polyunsaturated fatty acids, is located in the complexes composed of membranes or in the lipoprotein complexes. PUFAs are insoluble within the range of $\mathrm{pH}$ physiological values for most LO. $\mathrm{pH}_{\text {opt }}$ is more alkaline for 13-LO, and this type of LO does not require an interaction with the membrane surface for active transition. The enzyme translocation from cytosol to the membrane surface is one of the stages of regulation of the amount of LO catalysis products in the cell. A sorption to the membrane surface is described for most LO of plant and animal sources.

In animal cells the leukotrienes biosynthesis starts with the 5-LO translocation from cytosol to the nuclear membrane surface. Phospholipase $\mathrm{A}_{2}$ liberates $\mathrm{AA}$ and thus it is the forerunner to LO. The next enzyme in transforming HP LTA 4 synthase is also connected with the nuclear membrane [11]. It is assumed that the 5-LO exclusive sorption on the nuclear membrane surface depended on the membrane associated protein FLAP (five-lipoxygenase activating protein) [12] and a high affinity to zwitterionic phosphatidylcholine (PC) [24, 26], which is a dominant component of the nuclear membrane. FLAP also has a high affinity to the enzyme and PUFAs. Due to these properties, FLAP not only provides the enzyme association with specific membrane component but also regulates the enzyme interactions with the substrate creating local clusters of a high PUFAs concentration. The sequence of FLAP is $31 \%$ identical to the microsomal LTC $_{4}$ synthase [13]. FLAP can be associated with the endoplasmatic reticulum and lipid rafts, as the 5-LOX association with lipid rafts in mantle cell lymphoma was established [9]. Interestingly, FLAP was shown to be a part of secretory vesicles from the human neutrophils and exosomes of human monocyte-derived macrophages or monocyte-derived dendritic cells with LTA $_{4}$ hydrolase and LTC $_{4}$ synthase [14]. Probably, the complex of 5-LO, FLAP, LTA 4 hydrolase and LTC $_{4}$ synthase with the membrane vesicles can transfer out of the cell and the reaction products of this complex regulate the metabolism outside as compounds of distant action. Possibly, the mechanism for LO from other sources is similar, which is confirmed by the activation of potato tuber 5-LO in the presence of FLAP [15].

5-LO demonstrates the activity at the interface lipid:water. The reaction runs similarly to phospholipase $\mathrm{A}_{2}$. The heterophase nature of the reaction is determined by the presence in the enzymes structure of C2-like domain - N-terminal domain consisting of eight antiparallel $\beta$-sheets. This domain has some homology of its structure and function with $\mathrm{C} 2$ domain of phospholipases and proteinkinase C [17-19]. 
Lipoxygenase regulation in vivo and in vitro by lipid compounds

Similarity of mechanisms of these interactions provides a strong evidence of their universality in regulating the activity of key enzymes of the signaling systems. The residues in the ligand binding loops of $\beta$-sandwich bind $\mathrm{Ca}^{2+}$, cellular membranes, and coactosin-like protein (CLP) [4, 21-22]. C2 domain is characteristic of the association of membrane phospholipids and this process can be mediated by $\mathrm{Ca}^{2+}$ ions [23].

The interaction with membrane surface was described for the cloned 5-LO from leucocytes [24-25] and electrophoretically pure 15-LO from reticulocytes [26]. Using the biomembrane models consisting of phospholipids (lecithin or phosphatidylinositol) and linoleic acid, it has been shown that PUFAs oxidation carried out by potato 5-LO proceeds directly on the membrane [27-28]. The main factors providing the enzyme sorption on the membrane surface are hydrophobic and electrostatic interactions. It was established that with the replacement of certain amino acid residues in the 15-LO molecule from reticulocytes, the hydrophobic bonds are formed between $P h e^{70}, \operatorname{Trp}^{181}$, $\mathrm{Tyr}^{15}, \mathrm{Leu}^{71} \mathrm{Leu}^{195}$ and lipid part of the membrane; these are tryptophan residues in the case of 5-LO from leukocytes $\left(\operatorname{Trp}^{13}, \operatorname{Trp}^{75}, \operatorname{Trp}^{102}\right)$ [24]. Isolated from human 5-LO, the PLAT domain was able to aggregate and therefore could not be used to study the interactions. A substitution of the membrane-binding tryptophan 75 with glycine led to reducing the aggregation and increased its thermal stability [21].

The LO sorption on the membrane surface causes changes in the enzyme molecule, in particular, the changes in the protein configuration. Also, an additional regulatory effect on the LO activity influences the biochemical and physicochemical properties of the membrane matrix. According to [25], the 5-LO molecule from leukocyte is located on the membrane surface at approximately $45^{\circ}$; one of tryptophans (probably $\operatorname{Trp}^{75}$ ) is inserted into the hydrophobic layer to a depth of 8-9 $\mathrm{A}^{0}$ from the membrane centre. $\operatorname{Trp}^{13}$ and $\operatorname{Trp}^{102}$ interact with the surface but are not inserted into the lipophilic membrane layer. This collocation allows tight fixation of the enzyme molecule and reduces the distance between the LO active center and the membrane surface, where the substrate reaction occurs. Similar processes can significantly alter the enzyme conformation and its catalytic properties. The interaction of the 13-LO from soybeans with the surface of phosphatidylcholine micelles changes the enzyme specificity at the catalysis of equimolar mixture of 13-hydroperoxide and 9-hydroperoxide of linoleic acid [29].

\section{Phospholipids}

The composition of membrane structures is an important factor in the regulation of the enzyme sorption. The published data are contradictory when it concerns the influence of phospholipids (PL) with different charges on the LO activity (Table 1). For instance, a high affinity of the animal enzymes to phosphatidylcholine was shown, in contrast to anionic phospholipids [18, 24, 26, 35, 53]. During purification of 5-LO from human leukocytes, it was observed that the enzyme activity depends on microsomal membranes [30] since the synthetic phosphatidylcholine (PC) vesicles, which are similar to the cell membrane fraction, act as the enzyme stimulating factor. $\mathrm{PC}$ promoted $\mathrm{Ca}^{2+}$ stimulation of the 5 -LO activity in vitro [35]. In the presence of $\mathrm{Ca}^{2+}$, the isolated $\mathrm{C}_{2}$-like $\beta$-sheet domain of 5-LO has a higher affinity to the PC zwitterion vesicles than to the vesicles of anionic phosphatidylserine (PS) and phosphatidylglycerol. The selectivity of 5-LO association with the nuclear membrane is determined by the specificity of the enzyme binding with PC (a nuclear membrane is rich in PC) and this association is $\mathrm{Ca}^{2+}$-dependent [24-25]. Three tryptophans ( $\operatorname{Tr} \mathrm{p}^{13}$, $\operatorname{Trp}^{75}, \operatorname{Trp}^{102}$ ) were identified, which participate in the interactions of ligand-binding loop [2].

It is assumed that the 5-LO selectivity to PC is important for the enzyme contact with the nuclear environment [24] as $\beta$-sandwich is required for translocation of soluble 5-LO from cytosol to the nuclear membrane [55]. It is believed that calcium ions promote the association of C2-like domain of 5-LO (as well as phospholipase $\mathrm{A}_{2}$ ) with the $\mathrm{PC}$ membrane in two ways: local neutralization of anionic surface of the protein, and changing the orientation of aliphatic and aromatic side chains of amino acid residues in the $\mathrm{Ca}^{2+}$-binding loop, which leads to their incorpo- 
ration into the membrane and hydrophobic interaction [24]. The $\mathrm{Ca}^{2+}$-induced interaction with PC stabilizes 5-LO and the membrane, and results in the enzyme activation [18].

The other results were obtained in the study on the interaction of the potato tubers 5-LO with differently charged phospholipids. For this enzyme, the activat- ing effect of phosphatidic acid (PA) [48], phosphatidylinosite (PI) [27], phosphatidylserine (PS) [27] in the micellar system was demonstrated.

The differences in the PL effects on the enzymes from plant and animal sources can be explained comparing the affinity of these enzymes to diversely charged phospholipids, which translocate to the mem-

Table 1. Lipid compounds and action on lipoxygenase enzymes

\begin{tabular}{|c|c|c|c|}
\hline Lipid compounds & Enzyme & Action on enzyme & Reference \\
\hline PC vesicles & 5-LO human leukocytes & activation & {$[30]$} \\
\hline $\begin{array}{l}\text { 1-palmitoyl-2-arachidonoyl-sn- } \\
\text { glycero-3-phosphocholine }\end{array}$ & 5-LO human & activation of membrane binding & {$[25]$} \\
\hline $\begin{array}{l}\text { sulfated derivatives of } \\
\text { galactocerebroside }\end{array}$ & 5-LO human & inhibition in the cell & {$[31]$} \\
\hline 1-oleoyl-2-acetylglycerol & 5-LO human & stimulation by binding with C2-like domain & {$[32]$} \\
\hline $\begin{array}{l}\text { cholesterol, cholesterol sulfate, } \\
\text { cholesterol phosphate }\end{array}$ & 5-LO human & inhibition of activity & {$[33]$} \\
\hline arachidonic acid 15(S)-HETE & 5-LO human & enzyme translocation to the membrane & {$[34]$} \\
\hline $\mathrm{PC}$ & C2-like domain of 5-LO human & affinity to $\mathrm{PC}$ vesicles in $\mathrm{Ca}^{2+}$ presence & {$[35]$} \\
\hline NO-LA, NO-OA & human PMNL 5-LO & inhibition of activity & {$[36]$} \\
\hline $\begin{array}{l}\text { 5-HPETE, 12-HPETE, } \\
\text { 15-HPETE, 13-HPODE }\end{array}$ & 5-LO mammalian & enzyme activation & {$[37-38]$} \\
\hline 13-HODE & 15-hLO-1 & change of substrate specificity & [39] \\
\hline 15-HETE & $15 \mathrm{~S}-\mathrm{LO}$ & enzyme activation & {$[40]$} \\
\hline 12-HETE & 15-hLO-1 & $\begin{array}{l}\text { increase of substrate specificity towards } \\
\text { AA over LA }\end{array}$ & {$[41]$} \\
\hline oxo-lipids & 15-LO human & inhibition of activity & {$[42]$} \\
\hline (Z)-9-octadecenyl sulfate & 15-LO human & inhibition of activity & [43] \\
\hline 13-HODE & 15-hLO-2 epithelial & changing the substrate specificity & [41] \\
\hline 13-HPODE & 15-hLO-2 epithelial & effect on substrate specificity & [44] \\
\hline 13-HPODE & 15-LO-1 human reticulocyte & effect on substrate specificity & [44] \\
\hline $\begin{array}{l}\text { oxo-lipids: 5-oxo-ETE, 15-oxo- } \\
\text { ETE, 12-oxo-ETE }\end{array}$ & 12-LO human & inhibition of activity & {$[42]$} \\
\hline $\begin{array}{l}\text { 13(S)-hydroxyoctadeca- } \\
9(\mathrm{Z}), 11(\mathrm{E}) \text {-dienoic acid }\end{array}$ & 12S-LO human platelete & enzyme dimmerization & {$[45]$} \\
\hline PC, PI & 12-LO porcine leukocytes & inhibition of activity & [46] \\
\hline (Z)-9-octadecenyl sulfate & LO-1 soybean & inhibition of activity & [43] \\
\hline 12-HETE & LO-1 soybean & increase of substrate specificity & [47] \\
\hline $\mathrm{PC}$ vesicles & 13-LO soybean & $\begin{array}{l}\text { changes of equimolar mixture products } \\
\text { of } 13-\mathrm{HPODE} / 9-\mathrm{HPODE}\end{array}$ & [29] \\
\hline PA & 5-LO potato tubers & enzyme activation & {$[48-49]$} \\
\hline PI & 5-LO potato tubers & enzyme activation & [27] \\
\hline PS & 5-LO potato tubers & enzyme activation & [27] \\
\hline LHA & $\begin{array}{l}\text { 5-LO potato tubers } \\
\text { 12-LO porcine leukocytes } \\
\text { 15-LO rabbit reticulocyte } \\
\text { 13-LO soybean }\end{array}$ & inhibition of activity & {$[50-52]$} \\
\hline
\end{tabular}


Lipoxygenase regulation in vivo and in vitro by lipid compounds

brane through the same mechanism [19, 24]. Affinity to a particular lipid is associated with the enzyme localization in the cell. So, the affinity of phospholipase $\mathrm{A}_{2}$ and 5-LO from leukocytes to PC is determined by their location on the nuclear membrane surface where the molar moiety of phospholipid is $48 \%$. As regards protein kinase $\mathrm{C}$ and 5 -LO from potato tubers, they demonstrate affinity to anionic PL, which is explained by the sorption of these enzymes on the plasmalemma surface enriched in anionic PL. 1-palmitoyl-2-arachidonoyl-sn-glycero-3phosphocholine caused the enzyme connection and deeper penetration. This may assist 5-LO to be closer to the nuclear environment composed of lipids with a high content of arachidonic acid [25].

The 5-LO from animal sources interacts also with cationic phospholipids [18]. This interaction is stronger and occurs in the absence of calcium ions although they increase the enzyme activity. It was suggested that 5-LO can bind to the membrane in «productive» or «unproductive» manner although binding to the membrane surface does not activate 5-LO itself. In turn, it was demonstrated that anionic sulfated derivatives of galactocerebroside (sulfatides lipids) inhibit the 5-LO activity in the cell [31].

\section{Monoglycerides and diacylglycerols}

Monoglycerides and diacylglycerol are other types of lipids that can activate 5-LO. The most effective activating compounds are 1-oleoyl-2-acetylglycerol (OAG), 1-O-hexadecyl-2-acetyl-sn-glycerol and 1,2-dioctanoyl-sn-glycerol [32]. $\mathrm{Ca}^{2+}$ prevents the stimulating effect of OAG; there is no activating effect of OAG in the presence of phospholipids or cell membrane. The mutant 5-LO with three tryptophan residues (Trp13, - 75, - 102) in the C2-like domain was not stimulated by OAG. It was established that these residues are involved in the interaction of 5-LO with $\mathrm{OAG}$, and that gives us a reason to believe that $\mathrm{OAG}$ directly stimulates 5-LO by the interaction with phospholipid-binding site located in the C2-like domain. Another compound, diacylglycerol (DAG), is also required for the association of the enzyme with the nuclear membrane via the C2-like domain. Perhaps this mechanism is similar to the enzymes with $\mathrm{C} 2$ domains in their structure and was investigated for the protein kinase $\mathrm{C}$ in more details. The protein kinase $\mathrm{C}_{\varepsilon}$ deeply penetrates to the plasma membrane with $\mathrm{C} 2$ domain depending on the DAG generation due to the activity of phospholipase D / phosphatidic acid phosphatase [20]; the protein kinase C2 domain, activated by $\mathrm{Ca}^{2+}$ in phosphatidylserine-dependent way, binds to the membrane whereas the $\mathrm{C} 1$ domain is involved in the following immersion into the membrane and binding with DAG [18].

Uncharged glycerol seems to bind with the C2like domain without charge neutralization or changes in the orientation of the enzyme side chain caused by calcium ions. OAG, like $\mathrm{Ca}^{2+}$, protects 5-LO from the glutathione peroxidase- 1 inhibitor [32]. OAG is a result of the phospholipase $\mathrm{D}$ activity in the cell. Preincubation of human polymorphonuclear leukocytes with the phospholipase D inhibitor resulted in decreased synthesis of 5-LO products and blocked the 5-LO translocation from cytosol to the nuclear membrane [56], whereas OAG $(30 \mu \mathrm{M})$ reversed the inhibitory effect of 1-butanol on the synthesis of 5-LO products.

\section{Cholesterol, cholesterol sulfate}

The addition of cholesterol to the membrane preparation $(20 \%)$ reduces the enzyme activity by half [25] and cholesterol sulfate inhibits 5-LO in intact cells [33]. The fact that the leukotrienes production in the cell is regulated by cholesterol sulfate suggests the possibility of regulatory role of sulfotransferases/ sulfatases in the 5-LO products synthesis. Cholesterol sulfate regulates the activity of serine proteases, especially proteinkinase $\mathrm{C}$ isoforms, phosphatidylinositol-3-kinase, and chymotrypsin. Cholesterol phosphate, a synthetic anionic cholesterol derivative, acts as a more potent inhibitor of the leukotrienes synthesis than cholesterol sulfate [33]. According to the proposed mechanism of action, cholesterol and its derivatives may inhibit the protein-lipid interactions of the $\mathrm{C} 2$ domain of 5-LO enzyme with phospholipase A, which interacts strongly with zwitterion phosphatidylcholine. These interactions reduce the substrate release from 5-LO and thus decrease the enzyme activity in the cell. The cholesterol sulfate 
structure is similar to tirucallic acid, which directly binds to the 5-LO protein [57].

\section{Polyunsaturated fatty acids (PUFAs) and their derivatives}

There are the data demonstrating LO regulation by other lipids PUFAs. Interestingly, the 5-LO substrate arachidonic acid (AA) can regulate the 5-LO translocation in human neutrophils [34]. An application of the redox and competitive 5-LO inhibitors and experiments with the FLAP inhibitor and the intracellular $\mathrm{Ca}^{2+}$ chelator demonstrated that the AA-regulated 5-LO translocation is FLAP- and $\mathrm{Ca}^{2+}$-dependent. Altogether, the facts indicate the regulation of 5-LO translocation by AA which exists at/or separately of the catalytic site. Moreover, the oxidized derivatives also influence LO binding: 15(S)-HETE strongly induces the 5-LO translocation whereas 12(S)-HETE does not [34]. The specific LO products can also activate some types of LO. Perhaps, AA can bind directly with the enzyme molecule like it was described for the AA/protein kinase C [58]. AA was shown to activate directly protein kinase $\mathrm{C}$, involving a sequential $\mathrm{C}$ 2. This suggests a model of activation, in which an increase in intracytosolic $\mathrm{Ca}^{2+}$ leads to the interaction of arachidonic acid with the $\mathrm{Ca}^{2+}$-binding region; only after this step, does the C1A subdomain interact with arachidonic acid, leading to the complete activation of the enzyme. Comparison of phospholipase A2 (which has $\mathrm{C} 2$ and catalytic domains) and 15-LO [59], shows that the association of the membrane surface promotes the correct orientation of amino acid residues in the catalytic domain of 5-LO. The oxidized PUFAs are also able to influence the substrate specificity as it was described for 13-HODE, which can change the substrate specificity of 15-hLO-1 [47].

The products of one LO isozyme can be used to activate another LO isozyme, potentially regulating each other's activity in the cell. It have been shown that 5-HPETE, 12-HPETE, 15-HPETE, and 13-HPODE activated 5-hLO [37-38], 15-HETE activated 15S-LO, and 13-HODE activated epithelial 15-hLO-2 [40-41]. 13-HPODE activated epithelial 15-hLO-2 and reticulocyte 15-hLO-1 [44]. 12-HETE increased the substrate specificity of sLO-1 towards AA, when chal- lenged with an LA/AA mixture [39]. 12-HETE increases also the substrate specificity towards AA over LA for 15-hLO-1 [47]. One of the major 15-hLO-1 products, 13-(S)-hydroperoxy-9,11-(Z,E)-octadecadienoic acid (13-HPODE) from LA, upregulates the MAP kinase signaling pathway, the major 15-hLO-2 product, 15-(S)-HPETE from AA, down-regulated MAP kinase.

The reaction of nitric oxide and nitrite-derived species with PUFAs generated electrophilic fatty acid nitroalkene derivatives with $\mathrm{NO}_{2}$ : nitro-oleic (NO$\mathrm{OA}$ ) or nitro-linoleic acid (NO-LA) caused the concentration-dependent and irreversible inhibition of the 5-LO activity in human PMNL induced alkylation of enzyme Cys418. NO-FAs acted as a selective inhibitor for 5-LO and did not affect the activity of the platelet-type 12-LO (ALOX12) or 15-LO-1(ALOX15) in intact cells or recombinant protein [36]. Only 5-LO possessed functionally relevant nucleophilic amino acids within the catalytic center as potentially sensitive to an electrophilic attack.

Another N-containing derivative of PUFAs is linoleyl hydroxamic acid (LHA). LHA was shown to be an inhibitor for pt5-LO [50], soybean 15-LO [52, 60], porcine leucocytes 12-LO [51], rabbit reticulocyte 15LO. Using the model system of mixed micelles with constant molar ratio, it was found that LHA acted as a noncompetitive inhibitor of pt5-LO. The LHA oxydized derivatives exhibited the same inhibition effects as nonoxidized linoleyl hydroxamic acid on potato tuber 5-LO and porcine leucocyte 12-LO. The pt5-LO interactions with PA led to oxidation of nonspecific reaction substrate - LHA [61]. These results suggest that the enzyme activity can be potentially regulated by this modified inhibitor at the cell level.

A high affinity of lipids to lipoxygenase is of use for the synthesis lipoxygenase inhibitors. Some synthetic lipid derivatives inhibit the lipoxygenase catalysis. 1-oxyl-2,2,6,6-tetramethylpiperidinyl esters of octadecanoic and dodecanoic acids decrease the rate of the linoleic acid and linoleyl alcohol oxidation in the micellar system catalyzed by 5-LO [62-63]. The inhibition mechanism is proposed, which includes the interaction of lipophilic nitroxyl compounds with the radical intermediate formed in the catalytic process and the blocking of free radical transformation. It 
Lipoxygenase regulation in vivo and in vitro by lipid compounds

is demonstrated that the inhibition effect of fatty acid derivatives is determined by the substrate nature and the presence of allosteric effector.

\section{Oxo-lipids}

Recent publications have raised an interest to one more type of lipids - oxo-lipids, which are a large family of oxidized human lipoxygenase products. The electrophilic oxo-lipids, such as 15-oxo-5,8,11,13(Z,Z,Z,E)-eicosatetraenoic acid (15-oxo-ETE) and 12oxo-5,8,10,14-(Z,Z,E,Z)-eicosatetraenoic acid (12-oxoETE), are derived hydroperoxyeicosatetraenoic acid and hydroperoxyoctadecadienoic acid in the macrophage and are produced by conversion of the LO products. It was demonstrated that 15-oxo-ETE exhibited the highest potency against h12-LOX as an inhibitor. 12-oxo-ETE had comparable potency against h15-LOX-1 and inhibited h12-LOX. These data could indicate selective regulation of h12-LOX by the h15-LOX activity [42].

\section{Mechanisms of lipids influence}

\section{Physical and chemical properties of membranes}

An influence of the membranes structural components on the LO activity depends on their physical and chemical properties. The greatest effect on sorption process of LO has fluidity of the membrane structure determined by the number of 1,4-cis,cispentadien fragments consisting of fatty acids [25] and the membrane surface charge. For lipids of large unilamellar vesicles with increasing concentrations of cationic lipid 1,2-dymiristoil-glycero-3-etyl phosphocholine, the 5-LO activity enhances, but in the presence of anionic lipid 1,2-dipalmitoyl-sn-glycero-3-phosphocholine, the activity decreased [18]. The data obtained showed that unsaturation of lipid acyl chain is a key modulator of the 5-LO activity for both zwitterionic and anionic lipid membranes [25]. The influence of cholesterol and cholesterol sulfate (natural substance) on the LO activity is thought to be associated with changes in the physical properties of the membrane surface since these substances are known as agents increasing the mem- brane rigidity. As a component of membrane, cholesterol sulfate plays a stabilizing role preventing osmotic lysis, supporting adhesion of cells. The electric charge of the membrane surface affects the orientation of polar phosphatidylcholine main groups in the membrane: when the membrane surface charge is negative, the positively charged ends of the choline group move together into the membrane due to electrostatic attraction. The penetration of cholesterol sulfate stabilizes the membrane vesicles and reduces the lipid bilayer flexibility, namely, reduces the cholesterol membrane fluidity. The penetration of cholesterol residues reduces the permeability of membranes and increases their orderliness [33]. Thus, membrane fluidity is a key modulator of the membrane binding and activity of 5-LO [25]. Another lipid phosphatidic acid (PA) is able to separate into microdomains or induce a negative membrane curvature due to the charged small head groups located close to the bilayer acyl chains, a high affinity to bivalent cations and a tendency to the formation of intermolecular hydrogen bonds. These properties lead to destabilization of the PA lipid bilayer [64]. The length and unsaturation differences between substrates are essential for regulation of the LO activity as it was shown for the human epithelial 15-lipoxygenase-2 (15-LOX-2) with 13-(S)-HODE which changed the substrate specificity for arachidonic acid (AA) and $(\gamma)$-linolenic acid (GLA); it indicates that the allosteric structural changes in the active site discriminate between AA and GLA to achieve opposite kinetics effects [65].

The additional influence of PL is described as the change of thermodynamic parameters of lipoxygenase thermoinactivation [66]. The rate constants and activation energy of enzyme thermoinactivation were shown to increase in the presence of PA. It was suggested that hydrophobic forces play an essential role in the interaction between 5-LO and phosphatidic acid that can induce certain conformational changes of the enzyme molecule.

\section{Allosteric interactions}

It was reported that a number of natural and synthetic compounds affect the lipoxygenase activity by al- 


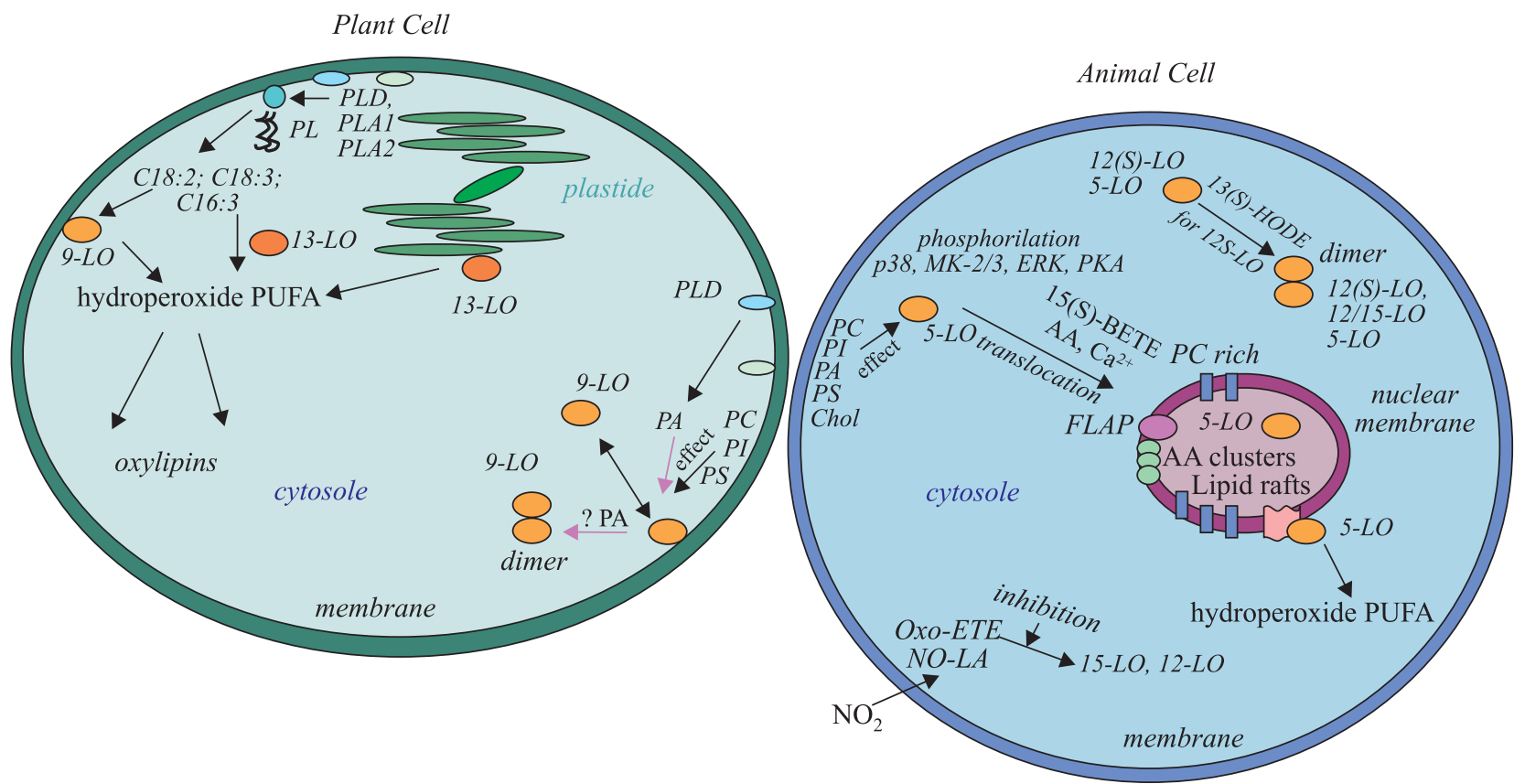

Fig. 1. The proposed scheme of relationship of lipid components and the enzyme lipoxygenase in plant and animal cells.

Plant cell. 9-LO and 13-LO are localized in either a soluble or an associated form with membrane (13-LO is connected with plastide membrane). LO oxidation of PUFAs takes place on membrane surface. PLD, PLA1, PLA2 liberate C18:2, C18:3 or C16:3 from phospholipids. PC, PI, PS and PA as natural membrane compounds can bind with 9-LO and change activity of LO regulated level of oxylipins. It is assumed that PA as allosteric activator can induce formation of 9-LO dimmers in plant cell like it was demonstrated for animal LOs.

Animal cell. In the resting cell, 5-LO is localized in either cytosol or in compartment inside the nucleus [22]. On activation, 5-LO translocates to the nuclear envelope rich with PC, where enzyme connects with FLAP. PLA liberates AA from phospholipids. FLAP is thought to participate in transfer of AA to LO. Molecules of AA increase translocation of 5-LO as well as 15(S)-HETE. PC, PI, PA and Chol since natural membrane compounds can bind with LOs and change activity of LO regulated level of LO metabolites. 5-LO can be a part of lipids rafts [9]. 12(S)-LO (in the presence of 13(S)-HODE) and 5-LO have ability to dimmerization. Oxo-lipids and NO-derivatives of PUFAs inhibit 15-LO and 12-LO in the cell.

LO - lipoxygenase; HP - hydroperoxide; PL - phospholipids; PA - phosphatidic acid; PC - phosphatidylcholine; PI - phosphatidylinosite; PS - phosphatidylserine; Chol -cholesterol; AA - arachidonic acid; LA - linoleic acid; PLD - phospholipase D; PLA1, PLA2 - phospholipase A1 and A2 respectively

losteric mechanism [43, 67-70]. A regulatory center exists in the enzyme molecule, which shows affinity to both substances: activator and linoleic acid as was described for $(R, S)$-2-hydroxy-2-trifluoromethyl-trans$n$-octadec-4-enoic acid (HTFOA), a powerful activator of pt5-LO [71]. The kinetic isotope effect studies demonstrated that unsaturated sulfonic acids are able to inhibit the activity of 15 -LO from reticulocytes and soybean LO-1 in the interaction with allosteric site of these enzymes $[68,70]$. Compounds (Z)-9-octadecenyl sulfate and (Z)-9-palmitoyl sulfate were replaced with the PUFA molecules considering two-fold higher affinity for regulatory site compared with the reaction substrate - linoleic acid. The affinity rised with an increase of carbon chain length and slightly depended on the effector charge. It is believed that hydrophobic bonds play a key role in the interaction with allosteric regulator center. This is supported by research of the nordihydroguaiaretic acid action. This compound is an inhibitor of soybean, human 12- and 15-LO [72]; in return hydrophobic derivatives increase LO catalysis through allosteric mechanism for human 15-LO. Therefore, it is thought that the lipophilicity moiety of effectors can change the regulatory influence of an active compound on the enzyme activity. The membranes con- 
Lipoxygenase regulation in vivo and in vitro by lipid compounds

taining lipids with unsaturated hydrocarbon chains have a significant stimulatory effect on the 5-LO activity [25]. An importance of lipophilicity of the LO allosteric regulator is coordinated with primacy of hydrophobic bonds in providing the enzyme sorption on the membrane surface and involving allosteric regulation of these processes.

The membrane phospholipids phosphatidylcholine (PC) and phosphatidylinosite (PI) caused almost complete disappearance of the S-shaped curve of $\mathrm{V}_{\mathrm{st}}$ depending on the substrate concentration of LA in micellar system in studies with highly purified preparation of 5-LO from potato tubers [73], and both phospholipids replaced the substrate molecules in the regulatory site of 5-LO. Both phospholipids (PC and PI) in the micellar system were shown to inhibit another lipoxygenase 12-LO from porcine leukocytes [46]. These lipids are able to compete with the substrate reaction LA in one of the centers (allosteric) and change the enzyme affinity to the substrate: PI decreases $\mathrm{K}_{s}$ and $\mathrm{K}_{n s}$, whereas PC causes the opposite effect. Anionogenic phospholipid phosphatidic acid (PA) demonstrated the activation of pt5-LO and replaced the substrate molecules in allosteric site, that decreased the non-enzymatic product level [74]. These data suggest the compensatory action of natural components of membrane in the LO catalysis.

The PLAT domain has an ability to participate in allosteric relationships. It plays a role in membrane affinity, allostery and substrate specificity. Removal of the PLAT domain affects the degree of allostery and moderates the communication pathway between the allosteric and catalytic sites [59].

The proposed scheme of relationship of the lipid components and the enzyme lipoxygenase in plant and animal cells is presented in Figure 1.

\section{Dimmerization of proteins}

The recent data point to the LO capability to transit to the dimmer state, which was demonstrated for the human 5-LO [75]. In aqueous solutions, the rabbit 12/15LO is mainly present as a hydrated monomer. The rabbit $12 / 15 \mathrm{LOX}$ functions as a monomer that dominates in solution, it dimmerizes at higher protein concentrations in the presence of salt and increasing de- gree of freedom of the N-terminal PLAT domain [75]. The human platelet-type $12 \mathrm{~S}-\mathrm{LOX}$ is stable as a dimer, in contrast to h-5LOX and r-12/15LOX, which are monomeric. The enzyme undergoes ligand-induced dimmerization in aqueous solutions under the action of allosteric effector 13(S)-hydroxyoctadeca-9(Z), 11 (E)-dienoic acid [76]. In the presence of $\mathrm{Ca}^{2+}, 5-\mathrm{LO}$ from rat basophilic leukemia (RBL-1) cells demonstrated the non covalent, monomer-dimer interaction, and both forms of the enzyme were present and only the high molecular weight species were active [77]. The possibility of LO dimmerization can be an explanation of the allosteric mechanism which is characteristic of majority of LOs.

\section{Conclusion}

5-LO can catalyze two reactions: the oxidation of AA and formation of leukotriene A4. It was established that the human 5-LO can form dimmers and it explains that one monomer catalyzes the formation of 5-HPETE and transmits to the second monomer to form leukotriene A4 [75]. The phenomenon of LO dimmerization can explain the ability of 5-LO to catalyze two reactions and an allosteric behavior of lipoxygenases. The LOX tendency to form dimmers, where two noncovalently linked enzyme molecules might work in unison [45], is a basis to understanding allosteric interactions. The dimmerization phenomenon seems to give a ground for explanation of the number of binding sites on the protein surface and the PL ability to decrease or increase this number, which leads to changing the LO cooperativity with the substrate. Lipid nature of the compounds can influence the allosteric properties of LOs changing the enzyme activity and level of its specific products. This leads to regulation of LO activity via influence on the protein-lipid interactions of $\mathrm{C} 2$ domain with the membrane, changes in the enzyme affinity, the LOs translocation from cytosole to the membrane surface, allosteric mechanism, and increasing selectivity towards the substrate type. The lipophilicity rate of effectors can change the regulatory influence of active compound on the enzyme activity. To explain the LO catalysis, it is necessary to consider the enzyme microenvironment and influence on the 
range of LO products as well as a conformational state of the protein molecule. Lipid microenvironment is essential for the LO activity. This should be considered in the regulation of a level of bioactive lipoxygenases products because of the possibility of an inhibitor molecule to be converted by the enzyme at contacting with PL in the cell.

\section{Acknowledgement}

The authors acknowledge Tetyana Odarich, MD for helpful assistance.

\section{REFERENCES}

1. Rakonjac M, Fischer L, Provost P, Werz O, Steinhilber D, Samuelsson $B$, Rådmark $O$. Coactosin-like protein supports 5-lipoxygenase enzyme activity and up-regulates leukotriene A4 production. Proc Natl Acad Sci U S A. 2006; 103(35): 13150-5.

2. Miller DK, Gillard JW, Vickers PJ, Sadowski S, Léveillé C, Mancini JA, Charleson P, Dixon RA, Ford-Hutchinson AW, Fortin $R$, et al. Identification and isolation of a membrane protein necessary for leukotriene production. Nature. 1990; 343(6255):278-81.

3. Kuhn H, Banthiya $S$, van Leyen $K$. Mammalian lipoxygenases and their biological relevance. Biochim Biophys Acta. 2015;1851(4):308-330.

4. Redmark O, Werz O, Steinhilber D, Samuelsson B. 5-Lipoxygenase, a key enzyme for leukotriene biosynthesis in health and disease. Biochim Biophys Acta. 2015;1851(4):331-339.

5. Grechkin AN, Tarchevsky IA. The lipoxygenase signaling system. Russian Journal of Plant Physiology 1999; 46(1): 114-23.

6. Feussner I, Wasternack C. The lipoxygenase pathway. Annu Rev Plant Biol. 2002;53:275-97.

7. Droillard MJ, Rouet-Mayer MA, Bureau JM, Lauriere C. Membrane-associated and soluble lipoxygenase isoforms in tomato pericarp (characterization and involvement in membrane alterations). Plant Physiol. 1993;103(4):1211-1219.

8. Braidot E, Petrussa E, Micolini S, Tubaro F, Vianello A, Macrm $F$. Biochemical and immunochemical evidences for the presence of lipoxygenase in plant mitochondria. $J$ Exp Bot. 2004;55(403):1655-62.

9. Boyd RS, Jukes-Jones R, Walewska R, Brown D, Dyer MJ, Cain $K$. Protein profiling of plasma membranes defines aberrant signaling pathways in mantle cell lymphoma. Mol Cell Proteomics. 2009;8(7):1501-15.

10. Peters-Golden M, Brock TG. 5-lipoxygenase and FLAP. Prostaglandins Leukot Essent Fatty Acids. 2003;69(2-3):99-109.

11. Soberman RJ, Christmas $P$. The organization and consequences of eicosanoid signaling. J Clin Invest. 2003;111(8): 1107-13.
12. Dixon RA, Diehl RE, Opas E, Rands E, Vickers PJ, Evans $J F$, Gillard JW, Miller DK. Requirement of a 5-lipoxygenase-activating protein for leukotriene synthesis. Nature. 1990; 343(6255):282-4.

13. Jakobsson PJ, Morgenstern R, Mancini J, Ford-Hutchinson $A$, Persson B. Membrane-associated proteins in eicosanoid and glutathione metabolism (MAPEG). A widespread protein superfamily. Am J Respir Crit Care Med. 2000;161(2 Pt 2):S20-4.

14. Esser J, Gehrmann U, D'Alexandri FL, Hidalgo-Estévez AM, Wheelock CE, Scheynius A, Gabrielsson S, Rådmark O. Exosomes from human macrophages and dendritic cells contain enzymes for leukotriene biosynthesis and promote granulocyte migration. J Allergy Clin Immunol. 2010;126(5):103240, 1040.e1-4.

15. Battu S, Moalic S, Rigaud M, Beneytout JL. Linoleic acid peroxidation by Solanum tuberosum lipoxygenase was activated in the presence of human 5-lipoxygenase-activating protein. Biochim Biophys Acta. 1998;1392(2-3):340-50.

16. Noguchi M, Miyano M, Kuhara S, Matsumoto T, Noma M. Interfacial kinetic reaction of human 5-lipoxygenase. Eur $J$ Biochem. 1994;222(2):285-92.

17. Medkova $M$, Cho $W$. Interplay of $\mathrm{C} 1$ and $\mathrm{C} 2$ domains of protein kinase $\mathrm{C}$-alpha in its membrane binding and activation. J Biol Chem. 1999;274(28):19852-61.

18. Pande AH, Moe D, Nemec KN, Qin S, Tan S, Tatulian SA. Modulation of human 5-lipoxygenase activity by membrane lipids. Biochemistry. 2004;43(46):14653-66.

19. Stahelin $R V$, Rafter JD, Das $S$, Cho $W$. The molecular basis of differential subcellular localization of $\mathrm{C} 2$ domains of protein kinase C-alpha and group IVa cytosolic phospholipase A2. J Biol Chem. 2003;278(14):12452-60.

20. Jose Lopez-Andreo M, Gomez-Fernandez JC, CorbalanGarcia $S$. The simultaneous production of phosphatidic acid and diacylglycerol is essential for the translocation of protein kinase Cepsilon to the plasma membrane in RBL-2H3 cells. Mol Biol Cell. 2003;14(12):4885-95.

21. Schrụder M, Hdfner AK, Hofmann B, Rådmark O, Tumulka F, Abele R, Dutsch V, Steinhilber D. Stabilisation and characterisation of the isolated regulatory domain of human 5-lipoxygenase. Biochim Biophys Acta. 2014;1842(10):1538-47.

22. Redmark $O$, Werz O, Steinhilber D, Samuelsson B. 5-Lipoxygenase, a key enzyme for leukotriene biosynthesis in health and disease. Biochim Biophys Acta. 2015;1851(4):331-339.

23. Rizo J, Sbdhof TC. C2-domains, structure and function of a universal $\mathrm{Ca}^{2+-}$ binding domain. J Biol Chem. 1998;273(26): 15879-82.

24. Kulkarni $S$, Das $S$, Funk CD, Murray D, Cho W. Molecular basis of the specific subcellular localization of the $\mathrm{C}_{2}$-like domain of 5-lipoxygenase. J Biol Chem. 2002;277(15): 13167-74.

25. Pande AH, Qin S, Tatulian SA. Membrane fluidity is a key modulator of membrane binding, insertion, and activity of 5-lipoxygenase. Biophys J. 2005;88(6):4084-94. 
Lipoxygenase regulation in vivo and in vitro by lipid compounds

26. Walther M, Wiesner R, Kuhn H. Investigations into calciumdependent membrane association of 15-lipoxygenase-1. Mechanistic roles of surface-exposed hydrophobic amino acids and calcium. J Biol Chem. 2004;279(5):3717-25.

27. Butovich IA, Parshikova TV, Babenko VM, Livarchuk LV, Kharchenko OV, Kukhar VP. Regulatory role of phospholipids in the oxidation of linoleic acid by 5 -lipoxygenase. Biol Membrane 1992; 9(6): 611-6.

28. Butovich IA, Kharchenko OV, Babenko VM. On the interfacial phenomena in lipoxygenase catalysis. Adv Prostaglandin Thromboxane Leukot Res. 1995;23:159-61.

29. Began G, Sudharshan E, Appu Rao AG. Change in the positional specificity of lipoxygenase 1 due to insertion of fatty acids into phosphatidylcholine deoxycholate mixed micelles. Biochemistry. 1999;38(42):13920-7.

30. Rouzer CA, Samuelsson B. On the nature of the 5-lipoxygenase reaction in human leukocytes: enzyme purification and requirement for multiple stimulatory factors. Proc Natl Acad Sci U S A. 1985;82(18):6040-4.

31. Sud'ina GF, Brock TG, Pushkareva MA, Galkina SI, Turutin $D V$, Peters-Golden $M$, Ullrich $V$. Sulphatides trigger polymorphonuclear granulocyte spreading on collagen-coated surfaces and inhibit subsequent activation of 5-lipoxygenase. Biochem J. 2001;359(Pt 3):621-9.

32. Hurnig C, Albert D, Fischer L, Hurnig M, Redmark O, Steinhilber $D$, Werz $O$. 1-Oleoyl-2-acetylglycerol stimulates 5-lipoxygenase activity via a putative (phospho)lipid binding site within the N-terminal C2-like domain. $J$ Biol Chem. 2005;280(29):26913-21.

33. Aleksandrov DA, Zagryagskaya AN, Pushkareva MA, Bachschmid M, Peters-Golden M, Werz O, Steinhilber D, Sud'ina $G F$. Cholesterol and its anionic derivatives inhibit 5-lipoxygenase activation in polymorphonuclear leukocytes and MonoMac6 cells. FEBS J. 2006;273(3):548-57.

34. Flamand N, Lefebvre J, Surette ME, Picard S, Borgeat P. Arachidonic acid regulates the translocation of 5-lipoxygenase to the nuclear membranes in human neutrophils. J Biol Chem. 2006;281(1):129-36.

35. Redmark O, Samuelsson B. Regulation of 5-lipoxygenase enzyme activity. Biochem Biophys Res Commun. 2005;338 (1):102-10.

36. Awwad K, Steinbrink SD, Frumel T, Lill N, Isaak J, Hdfner AK, Roos J, Hofmann B, Heide H, Geisslinger G, Steinhilber D, Freeman BA, Maier TJ, Fleming I. Electrophilic fatty acid species inhibit 5-lipoxygenase and attenuate sepsis-induced pulmonary inflammation. Antioxid Redox Signal. 2014;20 (17):2667-80.

37. Riendeau D, Falgueyret JP, Nathaniel DJ, Rokach J, Ueda $N$, Yamamoto $S$. Sensitivity of immunoaffinity-purified porcine 5-lipoxygenase to inhibitors and activating lipid hydroperoxides. Biochem Pharmacol. 1989;38(14):2313-21.

38. Rouzer CA, Samuelsson B. The importance of hydroperoxide activation for the detection and assay of mammalian 5-lipoxygenase. FEBS Lett. 1986;204(2):293-6.
39. Wecksler AT, Garcia NK, Holman TR. Substrate specificity effects of lipoxygenase products and inhibitors on soybean lipoxygenase-1. Bioorg Med Chem. 2009;17(18):6534-9.

40. Kilty I, Logan A, Vickers PJ. Differential characteristics of human 15-lipoxygenase isozymes and a novel splice variant of 15S-lipoxygenase. Eur J Biochem. 1999;266(1):83-93.

41. Wecksler AT, Kenyon V, Garcia NK, Deschamps JD, van der Donk WA, Holman TR. Kinetic and structural investigations of the allosteric site in human epithelial 15-lipoxygenase-2. Biochemistry. 2009;48(36):8721-30.

42. (60) Armstrong MM, Diaz G, Kenyon V, Holman TR. Inhibitory and mechanistic investigations of oxo-lipids with human lipoxygenase isozymes. Bioorg Med Chem. 2014;22(15): 4293-7.

43. Mogul R, Johansen E, Holman TR. Oleyl sulfate reveals allosteric inhibition of soybean lipoxygenase-1 and human 15-lipoxygenase. Biochemistry. 2000;39(16):4801-7.

44. Wecksler AT, Kenyon V, Deschamps JD, Holman TR. Substrate specificity changes for human reticulocyte and epithelial 15-lipoxygenases reveal allosteric product regulation. Biochemistry. 2008;47(28):7364-75.

45. Ivanov I, Shang W, Toledo L, Masgrau L, Svergun DI, Stehling S, Gymez H, Di Venere A, Mei G, Lluch JM, SkrzypczakJankun E, Gonzбlez-Lafont A, Kbhn H. Ligand-induced formation of transient dimers of mammalian 12/15-lipoxygenase: a key to allosteric behavior of this class of enzymes? Proteins. 2012;80(3):703-12.

46. Butovich IA, Kharchenko OV. [Role of phospholipids in the regulation of activity of porcine leukocyte 12-lipoxygenase]. Ukr Biokhim Zh (1999). 1999;71(1):38-43.

47. Wecksler AT, Jacquot C, van der Donk WA, Holman TR. Mechanistic investigations of human reticulocyte 15- and platelet 12-lipoxygenases with arachidonic acid. Biochemistry. 2009;48(26):6259-67.

48. Butovich IA, Babenko VM, Livarchuk LV, Mogilevich TV, Kukhar VP. Activation of the oxidation of linoleic acid by 5-lipoxygenase from potato tubers, induced by phosphatidic acid. Biol Membrane 1991; 56(6): 744-7.

49. Butovich IA, Tsys EV, Mogilevich TV, Kukhar VP. Influence of physicochemical factors on lipoxygenase oxidation of linoleic acid. Bioorg Chem. 1991; 17(9): 1273-80.

50. Butovich IA, Kharchenko OV, Bondarenko LB, Babenko $V M$, Livarchuk $L V$. Linoleyl hydroxamate as 5-lipoxygenase inhibitor. Biochemistry (Moscow) 1994; 59(6): 597-600.

51. Kharchenko OV, Cernjuk VN, Butovich IA. [Inhibitory effect of linoleyl-hydroxamic acid on the oxidation of linoleic acid by 12-lipoxygenase from porcine leukocytes]. $U \mathrm{kr}$ Biokhim Zh (1999). 1999;71(1):33-7.

52. Butovich IA, Lukyanova SM. Inhibition of lipoxygenases and cyclooxygenases by linoleyl hydroxamic acid: comparative in vitro studies. J Lipid Res. 2008;49(6):1284-94.

53. May C, Huhne M, Gnau P, Schwennesen K, Kindl H. The $\mathrm{N}$-terminal beta-barrel structure of lipid body lipoxygenase mediates its binding to liposomes and lipid bodies. Eur $J$ Biochem. 2000;267(4):1100-9. 
54. Zhang YY, Hammarberg T, Radmark $O$, Samuelsson $B, N g$ $C F$, Funk CD, Loscalzo J. Analysis of a nucleotide-binding site of 5-lipoxygenase by affinity labelling: binding characteristics and amino acid sequences. Biochem J. 2000;351 Pt 3:697-707.

55. Chen XS, Funk $C D$. The N-terminal «beta-barrel» domain of 5-lipoxygenase is essential for nuclear membrane translocation. J Biol Chem. 2001;276(1):811-8.

56. Albert D, Pergola C, Koeberle A, Dodt G, Steinhilber D, Werz $O$. The role of diacylglyceride generation by phospholipase D and phosphatidic acid phosphatase in the activation of 5-lipoxygenase in polymorphonuclear leukocytes. J Leukoc Biol. 2008;83(4):1019-27.

57. Boden SE, Schweizer S, Bertsche T, Dbfer M, Drews G, Safayhi H. Stimulation of leukotriene synthesis in intact polymorphonuclear cells by the 5-lipoxygenase inhibitor 3-oxotirucallic acid. Mol Pharmacol. 2001;60(2):267-73.

58. Lypez-Nicol6s R, Lypez-Andreo MJ, Marun-Vicente C, Gymez-Fernбndez JC, Corbalбn-Garcha S. Molecular mechanisms of PKCalpha localization and activation by arachidonic acid. The C2 domain also plays a role. J Mol Biol. 2006; 357(4):1105-20.

59. Walther M, Anton M, Wiedmann M, Fletterick R, Kuhn $H$. The N-terminal domain of the reticulocyte-type 15-lipoxygenase is not essential for enzymatic activity but contains determinants for membrane binding. J Biol Chem. 2002;277 (30):27360-6.

60. Butovich I, Bridnya V, Kukhar V. Linoleate-hydroxamic acid: a suicide inhibitor of lipoxygenase. Biochemistry-Moscow 1990; 55(7): 908-12.

61. Skaterna TD, Kopich VM, Tserniuk VM, Kharchenko OV. [Modeling of linoleyl hydroxamic acid influence on lipoxygenases in vitro]. Ukr Biokhim Zh (1999). 2009;81(6):59-69.

62. Vovk AI, Kharchenko OV, Kharitonenko AI, Kukhar'VP, Babǐ LB, Kazachkov MG, Mel'nik AK, Khil'chevskiü AN. [Hydrophobic nitroxyl radicals inhibit linoleyl alcohol oxidation by 5-lipoxygenase]. Bioorg Khim. 2004;30(4):436-40.

63. Kharytonenko HI, Skaterna TD, Mel'nyk AK, Babǐ LV, Kharchenko $O V$. [Interaction between 5-lipoxygenase and allosteric effector-sodium dodecyl sulfate]. Ukr Biokhim Zh (1999). 2008;80(3):31-9.

64. Kooijman EE, Chupin V, de Kruijff B, Burger KN. Modulation of membrane curvature by phosphatidic acid and lysophosphatidic acid. Traffic. 2003;4(3):162-74.

65. Joshi N, Hoobler EK, Perry S, Diaz G, Fox B, Holman TR. Kinetic and structural investigations into the allosteric and $\mathrm{pH}$ effect on the substrate specificity of human epithelial 15-lipoxygenase-2. Biochemistry. 2013;52(45):8026-35.

66. Skaterna TD, Kharytonenko HI, Kharchenko OV. [Thermoinactivation of potato 5-lipoxygenase and effect of phosphatidic acid on activation energy of denaturation]. Ukr Biokhim Zh (1999). 2010;82(2):22-8.

67. Butovich IA, Soloshonok VA, Solodenko VA, Kukhar'VP. [Activation of 5-lipoxygenase by lipophilic n-alkyl-contain- ing acids-an allosteric process]. Bioorg Khim. 1990;16(2): 270-1.

68. Sailer ER, Schweizer S, Boden SE, Ammon HP, Safayhi H. Characterization of an acetyl-11-keto-beta-boswellic acid and arachidonate-binding regulatory site of 5-lipoxygenase using photoaffinity labeling. Eur J Biochem. 1998;256(2):364-8.

69. Kharchenko OV, Kulinichenko HI, Butovych IA. [Kinetic mechanisms of linoleic acid oxidation by 5-lipoxygenase from Solanum tuberosum L]. Ukr Biokhim Zh (1999). 1999; 71(4):40-4.

70. Ruddat VC, Whitman S, Holman TR, Bernasconi CF. Stopped-flow kinetic investigations of the activation of soybean lipoxygenase- 1 and the influence of inhibitors on the allosteric site. Biochemistry. 2003;42(14):4172-8.

71. Butovich IA, Soloshonok VA, Kukhar VP. The unusual action of (R,S)-2-hydroxy-2-trifluoromethyl-trans-n-octadec4-enoic acid on 5-lipoxygenase from potato tubers. Eur $J$ Biochem. 1991;199(1):153-5.

72. Whitman S, Gezginci M, Timmermann BN, Holman TR. Structure-activity relationship studies of nordihydroguaiaretic acid inhibitors toward soybean, 12-human, and 15-human lipoxygenase. J Med Chem. 2002;45(12):2659-61.

73. Kharitonenko GI, Kharchenko OV. Phosphatidylcholine and phosphatidylinositol are allosteric regulators of 5-lipoxygenase from potato tubers. Biopolym Cell. 2008; 24(3): 254-9.

74. Skaterna TD, Kharchenko $O V$. [Effect of phosphatidic acid on the reaction of linoleic acid oxidation by 5-lipooxygenase from potatoes]. Ukr Biokhim Zh (1999). 2008;80(3):21-30.

75. Hufner AK, Cernescu M, Hofmann B, Ermisch M, Hurnig M, Metzner J, Schneider G, Brutschy B, Steinhilber D. Dimerization of human 5-lipoxygenase. Biol Chem. 2011;392(12): 1097-111.

76. Shang W, Ivanov I, Svergun DI, Borbulevych OY, Aleem AM, Stehling S, Jankun J, Kühn H, Skrzypczak-Jankun E. Probing dimerization and structural flexibility of mammalian lipoxygenases by small-angle X-ray scattering. $J \mathrm{Mol}$ Biol. 2011;409(4):654-68.

77. Parker $C W$, Aykent $S$. Calcium stimulation of the 5-lipoxygenase from RBL-1 cells. Biochem Biophys Res Commun. 1982;109(3):1011-6.

\section{Регуляція ліпоксигеназ in vivo та in vitro сполуками ліпідної природи}

Т. Д. Скатерна, В. М. Копіч, Г. І. Харитоненко, О. В. Харченко

Ліпоксигенази (ЛО) відомі як одні з ферментів перекисного окислення ліпідів. Більшість ЛО є розчинними ферментами та характеризуються аффіністю до мембран. Транслокація ферменту з цитозолю на мембранну поверхню одна з стадій регуляції рівня продуктів ліпоксигеназного каталізу у клітині. Сорбція на мембранну поверхню описана для більшості 
ЛОз з рослинних та тваринних джерел. Даний огляд представляє дані по регуляції ЛОз активності природніми та хімічно модифікованими речовинами ліпідної природи. Здатність ліпідів регулювати ЛО активність може здійснюватись через: білок-ліпідні взаємодії С2 домену з мембраною, зміну аффінності ферменту, транслокацію ЛОз, алостеричну регуляцію, збільшення селективності до субстрату. Регуляторний вплив активної сполуки на ферментативну активність залежить від рівня ліпофільності ефекторів. При поясненні ліпоксигеназного каталізу необхідно враховувати вплив мікрооточення ферменту на рівень ЛО.

К л юч о в і сл о в а: ліпоксигеназа, алостерична регуляція, фосфоліпіди, інгібування, активація

\section{Регуляция липоксигеназ in vivo и in vitro соединениями липидной природы}

Т. Д. Скатерная, В. Н. Копич,

А. И. Харитоненко, О. В. Харченко

Липоксигеназы (ЛО) известны как одни из ферментов перекисного окисления липидов. Большинство ЛО растворимые ферменты и характеризуются аффиностью к мембранам. Транслокация фермента из цитозоля на мембранную поверхность одна из стадий регуляции уровня продуктов липоксигеназного катализа в клетке. Сорбция на мембранную поверхность описана для большинства ЛОз из растительных и животных источников. Данный обзор представляет данные по регуляции ЛО активности природными и химически модифицированными соединениями липидной природы. Возможность липидов регулировать ЛО активность может осуществляться через: белок-липидные взаимодействия С2 домена с мембраной, изменение аффинности фермента, транслокацию ЛОз, аллостерическую регуляцию, селективность к типу субстрата. Регуляторное влияние активного соединения на ферментативную активность зависит от уровня липофильности еффекторов. При объяснении липоксигеназного катализа необходимо учитывать влияние микроокружения фермента на уровень ЛО продуктов.

Кл юче в ы е сл о в а: липоксигеназа, аллостерическая регуляция, фосфолипиды, ингибирование, активация.

Received 02.06.2015 